\title{
Evaluation of Watermelon Germplasm for Resistance to Phytophthora Blight Caused by Phytophthora capsici
}

\author{
Min-Jeong Kim, Chang-Ki Shim*, Yong-Ki Kim, Hyeong-Jin Jee, Sung-Jun Hong, Jong-Ho Park and \\ Eun-Jung Han \\ Organic Agriculture Division, National Academy of Agricultural Science, Suwon 441-707, Korea \\ (Received on March 19, 2012; Revised on November 20, 2012; Accepted on November 25, 2012)
}

\begin{abstract}
This study was conducted to determine the Phytophthora rot resistance of 514 accessions of watermelon germplasm, Citrullus lanatus var lanatus. About $46 \%$ of the 514 accessions tested were collections from Uzbekistan, Turkey, China, U.S.A., and Ukraine. Phytophthora capsici was inoculated to 45-day-old watermelon seedlings by drenching with $5 \mathrm{ml}$ of sporangial suspension $\left(10^{6}\right.$ sporangia/ml). At 7 days after inoculation, 21 accessions showed no disease symptoms while 291 accessions of susceptible watermelon germplasm showed more than $60.1 \%$ disease severity. A total of 510 accessions of watermelon germplasm showed significant disease symptoms and were rated as susceptible to highly susceptible 35 days after inoculation. The highly susceptible watermelon germplasm exhibited white fungal hyphae on the lesion or damping off with water-soaked and browning symptoms. One accession (IT032840) showed moderate resistance and two accessions (IT185446 and IT187904) were resistant to $P$. capsici. Results suggest that these two resistant germplasm can be used as a rootstock and as a source of resistance in breeding resistant watermelon varieties against Phytophthora.
\end{abstract}

Keywords : Citrullus lanatus var lanatus, Phytophthora resistance, sporangia

Phytophthora blight and rot caused by Phytophthora capsici Leon. and $P$. drechsleri Tuck. have been described as the most destructive diseases, as they have a wide host range that include pepper, tomato, eggplant, and most cucurbits such as cucumber, squash, pumpkins, watermelon and muskmelons (Erwin and Ribeiro, 1996; Gubler and Davis, 1996; Islam and Babadoost, 2004; Jee et al., 2000; Kim and Shon, 1991; Tian and Babadoost, 2004).

P. capsici causes seedling damping-off, leaf spot, foliar blight, root and crown rot, stem lesion and fruit rot (Erwin and Ribeiro, 1996; Gubler and Davis, 1996; Hassell and

\footnotetext{
*Corresponding author.

Phone) +82-31-290-0545, FAX) +82-31-290-0507

E-mail)Ckshim@korea.kr
}

Hausbeck, 2004; Jee et al., 2000). The first field symptom on Cucurbita crops is commonly crown rot. The crown rot of root causes the entire plant to completely collapse and die in a short period of time. Affected vine tissue turns brown in color, appears water-soaked, and often collapses.

Infected fruit develops dark, water-soaked lesions that which are commonly covered with white mold (Erwin and Ribeiro, 1996; Kim, 1995; Kim and Shon, 1991; Tian and Babadoost, 2004).

Fruit rot caused by $P$. drechsleri was first reported in Colorado and California, USA in the late 1930s. The disease was found sporadically in the U.S. until the 1980s, except in California where it occurred more regularly. Incidence increased notably in Florida, Georgia, North Carolina, New Jersey, Michigan, and the northeastern states. In some areas, the increase in incidence followed hurricane damage. Phytophthora blight also commonly affects pepper and less common on eggplant and tomato (Babadoost, 2004; Erwin and Ribeiro,1996).

Watermelons are susceptible to major soil-borne diseases that attack the roots, foliage, and fruits. The most common diseases of watermelon in all growth stages are anthracnose, Fusarium wilt, downy mildew, gummy stem blight, Phytophthora blight, root-knot nematode and viral diseases (Davis et al., 2007; Gunner et al., 2004; Gusmini et al., 2005; Hojo et al., 1991; Kim and Shon, 1991; Sowell, 1975).

Collar rot infection of watermelon caused by P. drechsleri was first recorded in Korea in Sungju in 1988 and second in Goryoung in 1989. The fungal pathogen attacked seedlings of watermelon, melon, and cucumber, and expectedly, seedlings of pepper and squash (Kim and Shon, 1991). Also, the first report in Korea of Phytophthora fruit and vine rot of watermelon caused by $P$. capsici was found in Euseong in1991 and in Bonghwa in 1993. The pathogen infected seedlings of watermelon, squash and peppers (Kim, 1995).

No single method currently available provides adequate control of Phytophthora blight. A combination of measures should be practiced to reduce Phytophthora blight on cucurbits (Babadoost, 2000; Hausbeck, 2004; Islam and Babadoost, 2004). An effective rotational period has not 
been identified yet. Two years has been shown to be insufficient, therefore the selection of a field where susceptible crops have not been grown for at least 3 years should be done (Jang et al., 2008; Kim and Kim, 2002; Noh et al., 2004).

Chemical control of vegetable crops gives good results for some pathogens, poor results against others pathogens such as bacteria, and practically no effects on viral pathogens. Moreover, reduction on the use of chemical treatments consequently lowers the health risks to farmers and consumers.

The phase-out of methyl bromide has driven the search for alternative methods of soil-borne pathogen control in watermelons. Alternative agricultural pesticides and other physical treatments are being tested and developed. Grafting with resistant rootstocks offers one of the best ways to avoid soil-borne disease attack (Babadoost et al., 2008; Kings et al., 2008).

The Middle Eastern countries and Korea are the major consumers and major production countries of watermelon (Lee et al., 2007; Robinson and Decker-Walters, 1997). Breeding of new varieties must be done taking into consideration consumer preference, yield potential, desired earliness, fruit size and shape, disease and pest resistance, and market demands (Jeffrey, 1975; Levi et al., 2001a; Marr and Tisserat, 1998; Rubatzky, 2001).

Since the early 20th century, breeding for plant disease resistance has been an important objective of most breeding programs and a major method for controlling plant diseases. Since the 1980s, molecular markers are being widely used as a principal tool in breeding programs of major crops. In particular, considerable efforts have been made to find molecular markers linked to disease and insect pest resistance genes (Moose and Mumm, 2008). DNA marker technology has been developed in commercial crop breeding programs since the early 1990s, and has proved helpful for the rapid and efficient transfer of useful traits into alternative varieties and hybrids (Tanksley, 1983).
Nonetheless, the classical screening method for resistance to several important diseases using greenhouse seedling tests remains useful, and provides several advantages (Munger et al., 1984; Norton et al., 1986; Song et al., 2004).

The objective of this study was to estimate the resistance of 514 accessions of watermelon germplasm to phytophthora rot for improving watermelon breeding efficiency using biological assay.

In our study, 514 accessions of watermelon germplasm from 63 countries were obtained from the National Agrobiodiversity Center in Korea. About $46 \%$ of watermelon germplasm originated from Uzbekistan, Turkey, China, U.S.A. and Ukraine (Table 1).

Twenty seeds (20) of each tested watermelon germplasm were replicated and disinfected with $2 \%$ sodium hypochlorite $(\mathrm{NaOCl})$ for two hours. The disinfected seeds were vigorously washed three times with distilled water and pregerminated on moist filter paper in Petri-dishes at $30^{\circ} \mathrm{C}$ for one-week under light and dark $(16 \mathrm{~h} / 8 \mathrm{~h})$ condition. Twenty seeds of pre-germinated watermelon germplasm were sown into 70-hole plastic seedling trays filled with a mixture of peat moss and horticultural soil. The seedlings were grown for 45 days in the greenhouse.

The Phytophthora rot pathogen, P. capsici (KACC 44716) was obtained from the Korea Agricultural Culture Collection (KACC) of the Rural Development Administration. We modified the method for the production of Phytophthora sporangia reported by Jee et al. (2000). To induce sporangia production, the pathogen was grown in $10 \% \mathrm{~V}-8$ agar for one week. The agar plate with fungal hyphae was placed under fluorescent light at room temperature. After one week, the matured sporangia were cold shocked at $4{ }^{\circ} \mathrm{C}$ for one hour, followed by $1 \mathrm{~h}$ equilibration at room temperature. The sporangia and zoospores were harvested from the mycelia using an autoclaved paint brush, and the concentration was adjusted to $10^{6}$ sporangia/ml using a hemocytometer. About 45-day old watermelon seedlings were inoculated by drenching with $5 \mathrm{ml}$ of sporangia

Table 1. Origin of 514 accessions of watermelon germplasm tested for resistance to Phytophthora capsici

\begin{tabular}{cl}
\hline \hline & \multicolumn{1}{c}{ Origin (Number of Accessions) } \\
\hline $\begin{array}{c}\text { More than } \\
11 \text { accessions }\end{array}$ & $\begin{array}{l}\text { Russia (89), Uzbekistan (43), Turkey (28), China (27), U.S.A. (26), Ukraine (24), Kazakhstan (19), Turkmenistan } \\
\text { (17), Japan (17), Georgia (16), Tajikistan (15), Korea (12), Azerbaijan (11), Unknown (58)* }\end{array}$ \\
\hline & Mongolia (8), Iran (6), Armenia (6), Vietnam (5), Senegal (5), Laos (5), India (5), Botswana (5), Israel (4), Somalia \\
& (3), Pakistan (3), Nepal (3), Mexico (3), Kyrgyzstan (3), Afghanistan (2), Bulgaria (2), Bolivia (2), Egypt (2), Ethio- \\
pess than & pia (2), Hungary (2), Philippines (2), North Korea (2), Sudan (2), Syria (2), Thailand (2), Taiwan (2), Australia (1), \\
Brazil (1), Chile (1), Colombia (1), Costa Rica (1), Cuba (1), Algeria (1), Honduras (1), Indonesia (1), Iceland (1), \\
& $\begin{array}{c}\text { Jordan (1), Kenya (1), Liberia (1), Libya (1), Moldova (1), Madagascar (1), Myanmar (1), Mozambique (1), Nigeria } \\
\text { (1), Netherlands (1), Tunisia (1), Yugoslavia (1), Zimbabwe (1), South Africa (1) }\end{array}$ \\
\hline Total & 63 countries (514)
\end{tabular}

*Unknown : These accessions have no information on origin. 


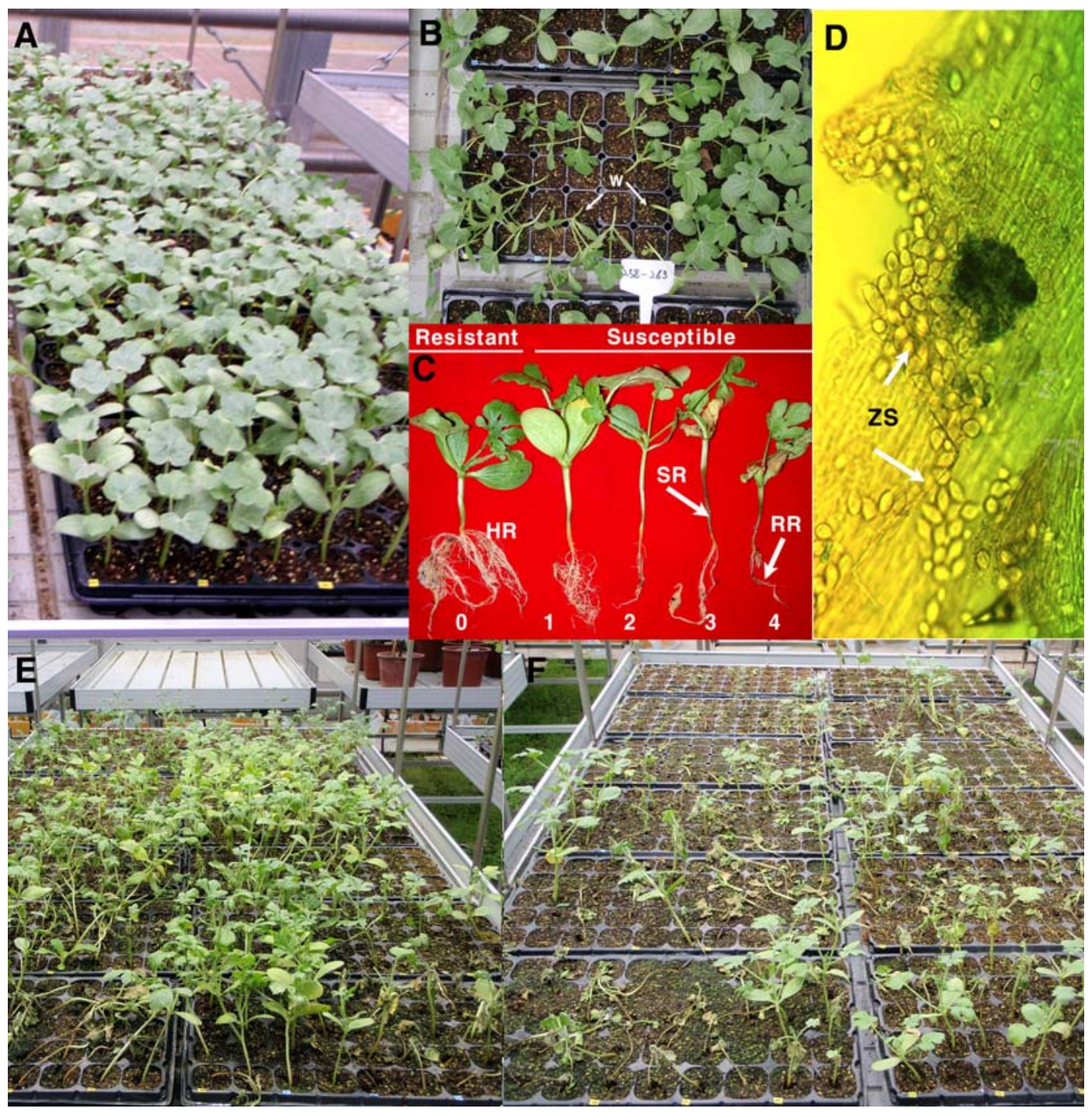

Fig. 1. Photographs show the preparation of healthy watermelon seedlings (A) and the occurrence of Phytophthora stem and root rot caused by Phytophthora capsici after inoculation $(\mathrm{B}, \mathrm{C})$ of $10^{6}$ zoosporangia/ml. Light microscopic observation of zoosporangia of $P$. capsici revealed on infected stem and root tissues of watermelon seedlings (D). Development of Phytophthora rots symptoms on watermelon germplasm at 7 days (E) and 35 days (F) after inoculation in greenhouse. W: wilt of plant, HR: healthy root, SR, RR: infected stem and root with $P$. capsici, ZS: sporangia.

suspension $\left(10^{6}\right.$ sporangia/ml $)$ and incubated for two days under saturated moist condition in the greenhouse (Fig. 1).

We designed that three experiments were performed for redundancy check and time-saving: a) the mass germplasm accession broad screening step, b) the early retest of the positive screening results step, and c) the final retest step. Seedling screening methods are the most commonly used among breeders to test new cultivars and lines for resistance to plant pathogens (Wehner and Shetty, 2000; Zhang et al., 1997).

Disease severity was determined for 35 days with seven days interval after the inoculation of sporangia suspension. We assessed the severity of phytophthora rot symptoms by assigning symptom grades based on visual inspection, as well as by measuring healthy and diseased root tissues (Fig. 1). The visible symptoms that appeared sequentially were crown rot, stem lesions, plant wilt, leaf defoliation, and damping-off. We determined the level of Phytophthora rot resistance of watermelon germplasm by scoring the disease severity: resistant $-0 \%$ disease severity; moderately resistant $-<20 \%$ disease severity; susceptible $-20.1 \%$ to $90 \%$ disease severity; and highly susceptible $->90.1 \%$ disease severity (Fig. 1 and Fig. 2).

Although many watermelon cultivars were developed throughout the world, there is an existing need to improve qualitative characteristics, especially for increased disease 


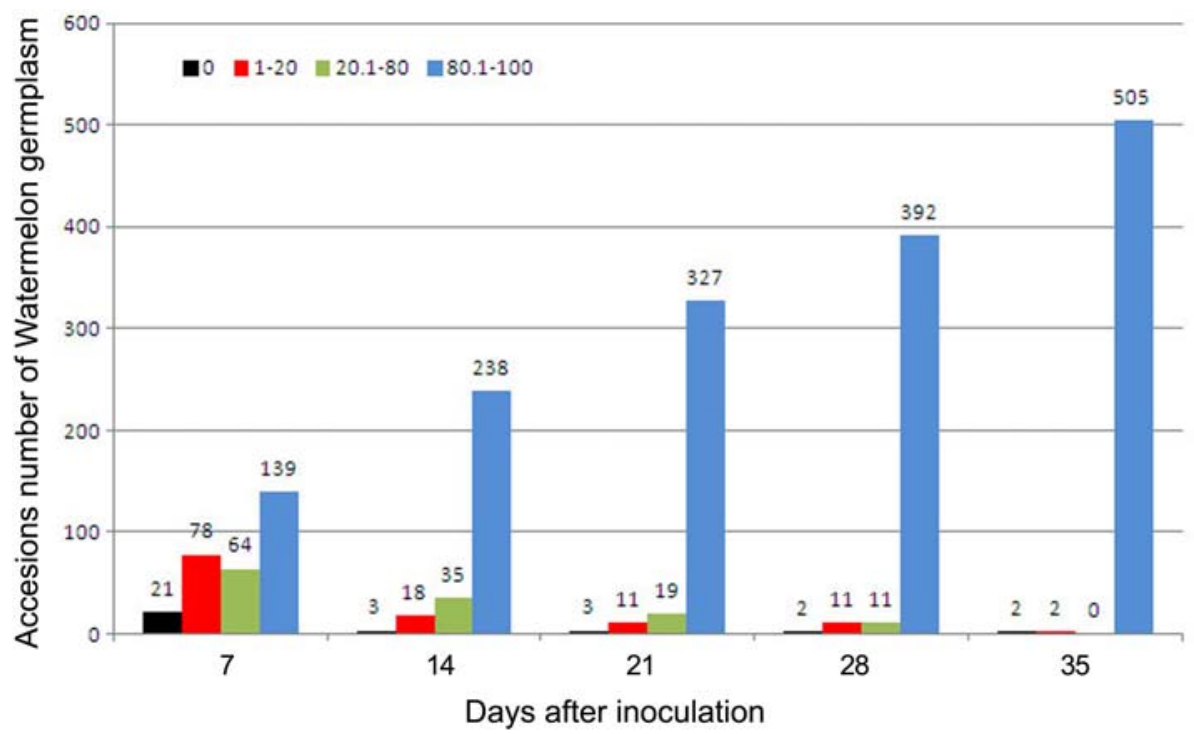

Fig. 2. Evaluation of 514 accessions of watermelon germplasm for resistance to Phytophthora rot at 7-day intervals for 35 days after inoculation with of $10^{6}$ sporangia/ml of $P$. capsici.

and insect pest resistance (Davis et al., 2007; Gunner et al., 2004; Gusmini et al., 2005; Hausbeck and Lamour, 2004; Tian and Babadoost, 2004).

In this study, the disease symptoms in stems and roots began to appear in the highly susceptible watermelon germplasm at 7 days after inoculation of $P$. capsici. From the 514 accessions tested, 139 accessions exhibited more than $90.1 \%$ disease severity of stem rot symptoms accompanied by seedling wilt. On the other hand, 21 accessions of the tested watermelon germplasm did not show any disease symptom (Fig. 1 and Fig. 2).

Zoospores of $P$. capsici were obtained from infected tissues of inoculated seedlings for microscopy observation. Observation of epidemiological and phytophthora rot symptoms was conducted by mounting the specimens in glass slides with water, without fixation, for the light microscope examination. Light microscopy observation was made using a Nikon microscope (Eclipse 80i, Japan) fitted with a 40/0.7 objective and a 2x magnification changer. Data were recorded on a CCD camera (Nikon, Japan) using a video generator (Nikon Digital Sight DS-U1, Japan).

Microscopy observations showed that oospores established successfully, with very high population density, on the surface of the stem and root of susceptible watermelon germplasm. At 14 days after inoculation, the highly susceptible accessions showed the white fungal hyphae on the lesion of Phytophthora rot or post-emergence damping off with water-soaked and brown black lesion near the root crown (Fig. 1D). Four accessions showed resistance, at 14 days after inoculation, while 18 accessions had moderate resistance having less than $20 \%$ disease severity. Rated susceptible were 256 accessions having $20.1-80.0 \%$ disease severity, while 237 accessions showed highly susceptible symptoms ( $>90.1 \%$ disease severity) such as brownish lesions, sudden wilt, and leaf defoliation (Fig. 1E and Fig. 2).

At 21 days after inoculation, three accessions exhibited resistance, 11 with moderate resistance, 174 susceptible, and 326 highly susceptible, which exhibited whole plant wilt, stem and root rot, and seedling death (Fig. 2).

Of the 514 accessions of watermelon tested, only three accessions, Au Jubilant (IT185446), K-4976 (IT187904), and HF (IT032840), showed resistance to Phytophthora rot 28 days after inoculation. Three accessions, namely, Hait Kara (IT203070) and two accession of unknown origin (IT203070, and K134377), showed moderate resistance to Phytophthora rot by scoring less than $10 \%$ disease severity. Meanwhile, 117 accessions showed susceptible reactions to the disease while 391 accessions showed highly susceptible symptoms such as leaf defoliation, damping-off, and seedling death and scored more than $90.1 \%$ disease severity (Fig. 2).

At 35 days after inoculation, three accessions of watermelon germplasm, Au Jubilant (IT185446), K-4976 (IT187904), and HF (IT032840) showed significantly highlevel of resistance to P. capsici and were scored with $0 \%$ of disease severity with high inoculums density of $10^{6}$ sporangia/ml under green house (Fig. 1F and Fig. 3).

Phytophthora blight has become a serious threat to production of cucurbit crops in the world, causing up to $100 \%$ yield loss (Babadoost, 2004; Hausbeck and Lamour, 2004). The pathogen can survive between crops as oospores or mycelium in infected tissues. Zoospores are resistant to 


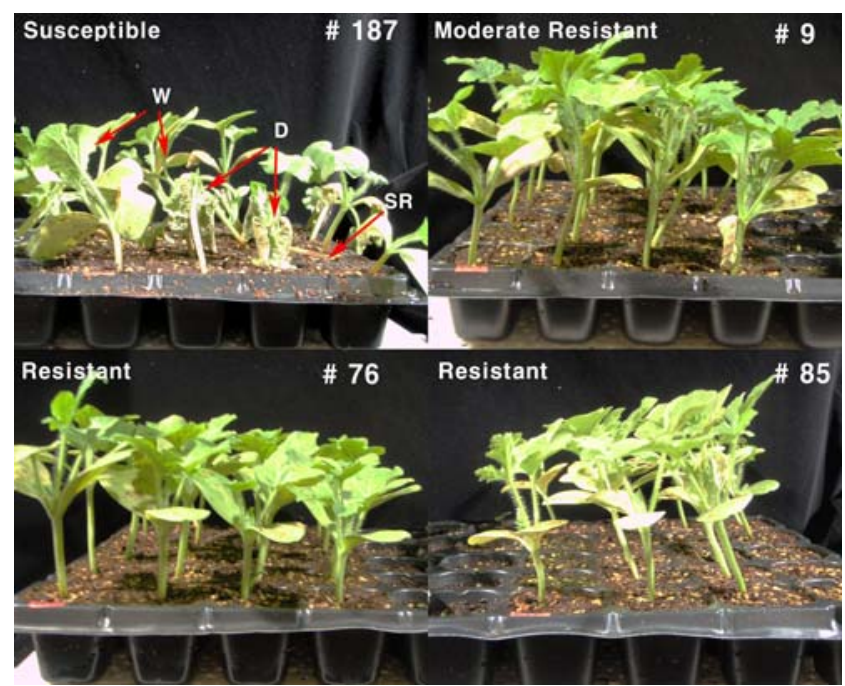

Fig. 3. Comparison of susceptible (IT199836), moderate resistant (IT032840) and resistant (IT185446 and IT187904) accession of watermelon germplasm to Phytophthora rot at 35 days after inoculation with $10^{6}$ zoosporangia/ml suspension of Phytophthora capsici. W, wilt of plant; D, whole plant death; SR, stem and root rot.

desiccation, cold temperatures, and other extreme environmental conditions, and can survive in the soil, in the absence of a host plant, for many years. Especially, $P$. capsici is a soilborne pathogen that can survive in the field for several years (Erwin and Ribeiro, 1996; Hausbeck and Lamour, 2004; Jee et al., 2000; Kim and Kim, 2002; Pavon et al., 2008).

Sources of resistance to Phytophthora rot must be identified in the germplasm so the trait can be incorporated into acceptable cultivars. In our results, the three Phytophthora rot resistant watermelon germplasm were monitored up to full flowering or early fruit formation stages and showed no visible sign or symptoms on the whole plant. Two candidate watermelon germplasm, Au Jubilant (IT185446) and K4976 (IT187904), may be introduced as cultivars for having improved Phytophthora rot resistance and better quality than other commercial varieties.

Au Jubilant cultivar was previously reported as the inbred line used in the cross Jubilee $\times$ PI 271778 which has performed well in field plantings with high yields of excellent quality fruits. Also, Au Jubilant, which originated from PI 271778, has shown multiple resistances to race 2 anthracnose, fusarium wilt, and gummy stem blight in tests in Alabama and other Southern Agricultural Experiment States in USA (Norton et al., 1986; Sowell, 1975).

Although conventional plant breeding had a significant impact on developing crops with disease and insect pest resistance, the time-consuming process of selection, making crosses and backcrosses, and the evolution of new virulent pathogens have always posed challenges (Moose and Mumm,
2008).

The National Watermelon Association, a grower's consortium, rank Phytophthora fruit rot as a top research priority in watermelon improvement programs (Morrissey, 2006). Although many watermelon cultivars have been developed throughout the world during the last century, there is little information regarding their ancestries (Levi et al., 2001b). The germplasm base in watermelon has actually quite narrow genetic diversities in Korea (Huh et al., 2008).

In our results, two watermelons germplasm resistant to Phytophthora rot survived past the flowering stage with no sign or symptoms on the whole plant. These genetic resources can be used as sources of resistance for new and existing cultivars, and as rootstock for Phytophthora blight resistant seedlings.

\section{Acknowledgements}

This study was carried out with the support of "Cooperative Research Program for Agricultural Science \& Technology Development (Project No. PJ90712103)", Rural development Administration, Republic of Korea.

\section{References}

Babadoost, M. 2000. Outbreak of Phytophthora foliar blight and fruit rot in processing pumpkin fields in Illinois. Plant Dis. 84:1345.

Babadoost, M. 2004. Phytophthora blight: A serious threat to cucurbit industries (http://www.apsnet.org/publications/ apsnetfeatures/Pages/PhytophthoraBlight.aspx).

Babadoost, M., Tian, D., Islam, S. Z. and Pavon, C. 2008. Challenges and options in managing Phytophthora blight (Phytophthora capsici) of cucurbits. In: M. Pitrat, (ed) Cucurbitaceae 2008, Proceedings of the IXth EUCARPIA meeting on genetics and breeding of Cucurbitaceae, INRA, Avignon, France, pp. 399-406.

Davis, A. R., Levi, A., Tettech, A., Wehner, T., Russo, V. and Pitrat, M. 2007. Evaluation of watermelon and related species for resistance to race $1 \mathrm{~W}$ powdery mildew. J. Amer. Soc. For Hort. Sci. 132:790-795.

Erwin, D. C. and Ribeiro, O. K. 1996. Phytophthora Disease Worldwide. APS Press. St. Paul, MN 562 pp.

Gubler, W. D. and Davis, R. M. 1996. Phytophthora Root and Crown Rot. In: Compendium of Cucurbit Diseases, T. A. Zitter, D. L. Hopkins, and C. E. Thomas, (eds). APS Press, St. Paul, MN. pp. 19-20.

Gunner, N., Pesic-Van Esbroeck, Z. and Wehner, T. 2004. Inheritance of resistance to the Watermelon strain of Papaya ringspot virus in Watermelon. HortScience 39:1175-1182.

Gusmini, G., Song, R. H. and Wehner, T. C. 2005. New sources of resistance to gummy stem blight in watermelon. Crop Sci. 45:582-588. 
Hassell, R. L. and Hausbeck, M. 2004. Phytophthora lessons learned: Irrigation water and snap beans. The Vegetable Growers News 38:2829.

Hausbeck, M. K. and Lamour, K. H. 2004. Phytophthora capsici on vegetable crops: research progress and management challenges. Plant Dis. 88:1292-1303.

Hojo, H., Pavan, M. A. and Silva, N. 1991. Aggressiveness of Papaya ringspot virus-watermelon strain on watermelon cultivars. Summa Phytopathologia 17:188-194.

Huh, Y. C., Solmaz, I. and Sari, N. 2008. Morphological characterization of Korean and Turkish watermelon germplasm. In: Pitrat, M. (ed) Cucurbitaceae 2008, Proceedings of the IXth EUCARPIA meeting on genetics and breeding of Cucurbitaceae, INRA, Avignon, France, pp. 399-406.

Islam, S. Z. and Babadoost, M. 2004. Evaluation of selected fungicides for control of Phytophthora blight of processing pumpkin. Fung. \& Nemat. Tests 59:V129.

Jang, S. W., Kim, H. D., Yi, E. S. and Rho, Y. T. 2008. Incidence of Phytophthora rot caused by Phytophthora capsici Leon. in squash field and cultivar resistance. Kor. J. Hort. Sci. Technol. 26:484-489.

Jee, H. J., Cho, W. D. and Kim, C. H. 2000. Phytophthora diseases in Korea. Rural Development Administration, Suwon, Korea. pp. 226.

Jeffrey, C. 1975. Further notes on Cucurbitaceae: III. Some African taxa. Kew Bul. 30:475-493.

Kim, B. S. 1995. Fruit and vine rot of watermelon caused by Phytophthora capsici. Korean J. Plant Pathol. 11:98-99.

Kim, B. S. and Shon, E. Y. 1991. Fruit and stem rot of watermelon caused by Phytophthora drechsleri Tucker. Korean J. Plant Pathol. 7:48-51.

Kim, C. H. and Kim, Y. K. 2002. Present status of soil-borne disease incidence and scheme for its integrated management in Korea. Res. Plant Dis. 8:156-161.

King, S.R., Davis, A.R., Liu, W. and Levi, A. 2008. Grafting for disease resistance. HortScience. 43:1673-1676.

Lee, J. M., Choi, G. W. and Janick, J. 2007. Horticulture in Korea. Kor. Soc. Hort. Sci. pp. 56-61.

Levi, A., Thomas, C.E., Wehner, T. C. and Keinath, A. P. 2001 a. Genetic diversity among watermelon (Citrullus lanatus and Citrullus colocynthis) accessions. Genetic Resources and Crop Evolution. Kluwer Academic Publishers, Netherlands 48: 559-566.

Levi, A., Thomas, C. E., Wehner, T. C. and Zhang, X. 2001b. Low genetic diversity indicates the need to broaden the genetic base of cultivated watermelon. Amer. J. Hort. Sci. 36:1096-1101.

Marr, C. W. and Tisserat, N. 1998. Commercial vegetable production: Watermelon. Kansas State University Agricultural Experiment Station and Cooperative Extension Service. MF-1107.

Miles, C. 2004. Icebox watermelons. In: Crop Production, Vegetable Research and Extension. Washingston State University. Vancouver Research and Extension Center, Vancouver, USA. (http://www.wsu.edu/watermelons. Date accessed: 18 July
2007).

Moose, S. P. and Mumm, R. H. 2008. Molecular plant breeding as the foundation for $21^{\text {st }}$ century crop improvement. Plant Physiol. 147:969-977.

Morrissey, B. 2006. The Vineline, 7-10.

Munger, H. M., More, T. A. and Awni, S. 1984. A preliminary report on screening watermelon for resistance to watermelon mosaic virus 1 and 2. Cucurbit Genet. Coop. Rep. 7:61-62.

National Watermelon Promotion Board, Production Statistics. 2005. [Online]. (http://www.watermelon.org/watermelon_statistics. asp.[3 March 2009].

Noh, J. J., Lee, K. K., Kim, G. C., Kim, W., Ko, B. R., Choi, J. S. and Choi, Y. G. 2004. Changes in density of Phytophthora capsici Leonian and incidence of Phytophthora root and fruit rot in field-grown watermelon on different repeated cropping years. Kor. J. Hort. Sci. Technol. 22:49.

Norton, J. D., Cosper, R. D., Smith, D. A. and Rymal, K. S. 1986. 'AU-Jubilant' and 'AU-Producer' watermelon. Hort Sci. 21:1460-1461.

Pavón, C. F., Babadoost, M. and Lambert, K. N. 2008. Quantification of Phytophthora capsici oospores in soil by sieving-centrifugation and real-time polymerase chain reaction. Plant Dis. 92:143-119.

Robinson, R. W. and Decker-Walters, D. S. 1997. Cucurbits. CAB Int. University Press, Oxon (GB) 226 pp.

Rubatzky, V. E. 2001. Origin, distribution and uses. In: Maynard D. N. (ed) Watermelons: Characteristics, production and marketing. ASHS Press, Alexandria, VA., pp. 21-26.

Song, V., Gusmini, G. and Wehner, T. C. 2004. Screening the watermelon germplasm collection for resistance to gummy stem blight. Acta Hort. 637:63-68.

Sowell, G. 1975. An additional source of resistance to gummy stem blight in watermelon. Plant Dis. Rep. 59:43-415.

Tanksley, S. D. 1983. Molecular markers in plant breeding. Plant Mol. Biol. Rep:3-8.

Taylor, M. J. 2002. Trends in World Cucurbit Production, 1991 to 2001. ASHS Press, Alexandria, VA, pp. 373-379.

Tian, D. and Babadoost, M. 2004. Host range of Phytophthora capsici from pumpkin and pathogenicity of isolates. Plant Dis. 88:485-489.

Wehner, T. C. and Shetty, N. V. 2000. Screening the cucumber germplasm collection for resistance to gummy stem blight in North Carolina field tests. Hort Sci. 35:1132-1140.

Wehner, T. C., Shetty, N. V. and Elmstrom, G. W. 2001. Breeding and seed production. In: Maynard, D. N. (ed.). Watermelons: Characteristics, production, and marketing. ASHS Press, Alexandria, Va. p. 27-73.

Zhang, Y. P., Kyle, M., Anagnostou, K. and Zitter, T. A. 1997. Screening melon (Cucumis melo) for resistance to gummy stem blight in the greenhouse and field. Hort. Sci. 32:117-121.

Zohary, D. and Hopf, M. 2000. Domestication of Plants in the Old World, $3^{\text {rd }}$ ed. Oxford University Press, p. 193. 